\title{
Prediction of Wind Erosion over a Heritage Site: A Case Study of Yongling Mausoleum, China
}

\author{
Xiaoyu Wang*, Jinzhu Meng, Tianwei Zhu, and Jingyu Zhang \\ School of Architecture \& Civil Engineering, Shenyang University of Technology, Shenyang, China \\ *Corresponding author: 704216608@qq.com \\ \# Equal Contribution
}

\begin{abstract}
To protect heritage buildings better, a method exploiting computational fluid dynamics (CFD) was developed for the analysis of wind erosion at a heritage site. Over a two-year period, we collected measurements of hourly weather data at Xinbin County to obtain statistics of wind speeds and directions for the Yongling Mausoleum. Subsequent results from CFD simulations show that before greening, with wind speeds reaching $10 \mathrm{~m} / \mathrm{s}$, certain structures (southwest-facing corners, doors and windows on open sides, places where swirling winds develop, and eaves of sloping roofs) of four heritage buildings were eroded more severely. With appropriate greening, plants may exert their unique ecological presence to better protect heritage buildings and their historical environments. After greening, the severity of damage to these vulnerable structures by wind was reduced. With wind speeds reaching $10 \mathrm{~m} / \mathrm{s}$, the average pressure on the structures of each building was $0.41-27.85 \mathrm{~Pa}$, representing a reduction of $2.4 \%-75.6 \%$ from pressures before greening. We also constructed a 1:500-scale model to verify in experiments the correctness of CFD simulation qualitatively. The CFD simulations were found to provide an effective method to investigate and predict wind erosion of the heritage site.
\end{abstract}

KEYWORDS computational fluid dynamics (CFD), numerical simulation, wind erosion, greening plan, heritage conservation

Received August 28, 2019; accepted December 16, 2019.

\section{Introduction}

Yongling Mausoleum is located in Yongling, Xinbin County, Fushun City, Liaoning Province, China. Built for the ancestors of the Qing imperial family and known as 'the First Mausoleum', Yongling Mausoleum is the most respected imperial mausoleum of its kind, with the most distinguishing characteristics among the mausoleums of the Qing Dynasty. Compared with other imposing mausoleums, it highlights the elegant but unpretentious features of the Qing Dynasty while embodying the building construction styles of the Jurchen, an ancient tribal people who were gifted at fishing and hunting in China. In 2004, the three mausoleums of Shengjing (namely, Fuling, Zhaoling, and Yongling Mausoleums), were included in UNESCO's World Heritage Site List.

The preservation of heritage buildings is very important, but even without human influences there are many environmental factors affecting their conservation. The most relevant factors are wind, ground-water, humidity, earthquakes, and vibrations. Wind erosion can be one of the main causes of damage to heritage buildings (Zhang and Cheng 2014; Pineda and Iranzo 2017; Zhan et al. 2016). First, wind may pick up sand and dust particles that scour the surfaces of heritage buildings; second, wind may cause heritage building surfaces to dry and crack. However, little work has been done concerning the effects of wind erosion at the Yongling Mausoleum, which is located in a windy region.

The objective of this work is to present a method that employs CFD tools in the analysis of wind erosion at a heritage site, in particular the contribution of particleladen wind in the material abrasion of exposed surfaces. The aim is also to demonstrate whether CFD simulations are suitable at predicting the effectiveness of possible protection measures, such as greening programs, which have 

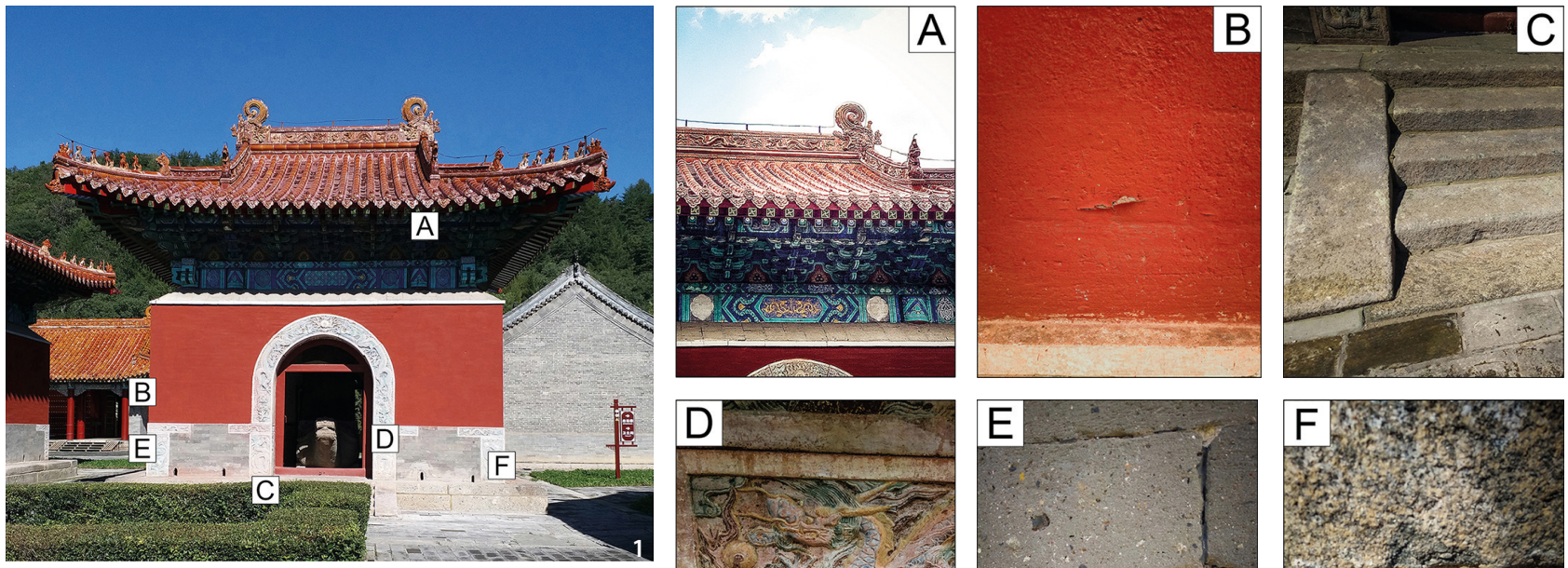

A. Abrasion on roof rafters.

B. Sand scratches on the wall.

C. Holes on the outdoor steps.

D. Abrasion on the frame stones of the door

E. Holes on the walls.

F. Holes on the walls.
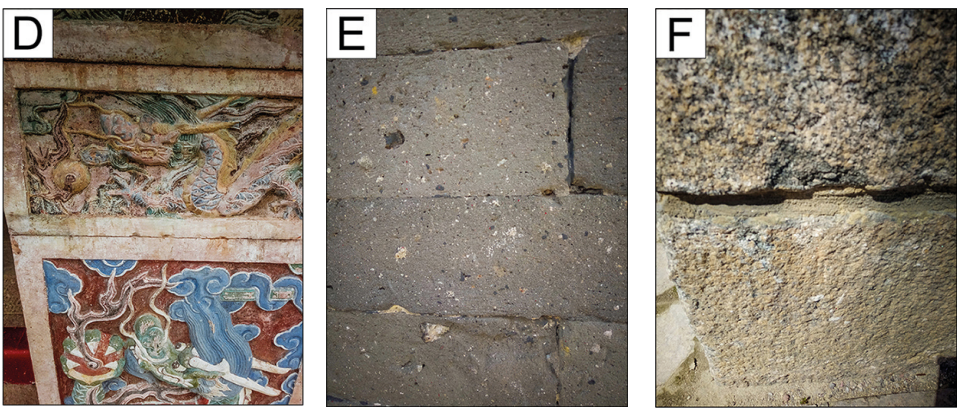

Figure 1 Present situation of Jingzu Monument Building (Source: Xiaoyu Wang).

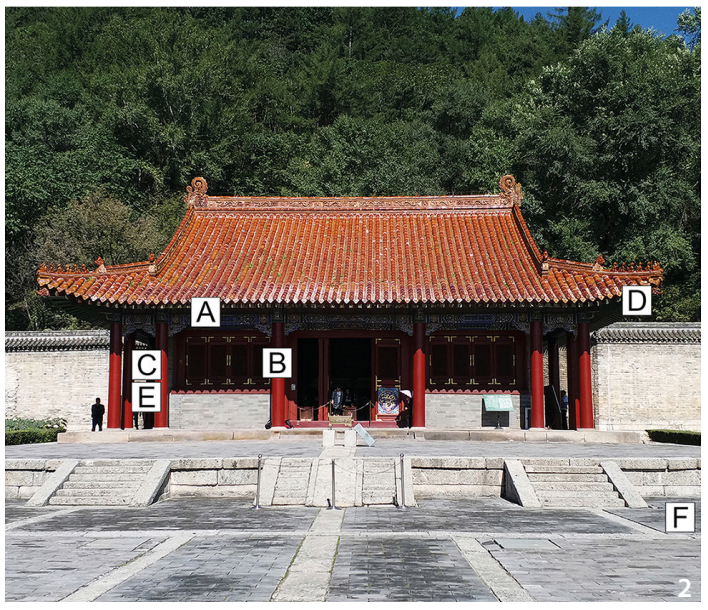

A. Abrasion on roof rafters.

B. Holes on the columns

C. Holes on the walls.

D. Abrasion on the corner beam.

E. Holes on the walls.

F. Abrasion on the outdoor ground.
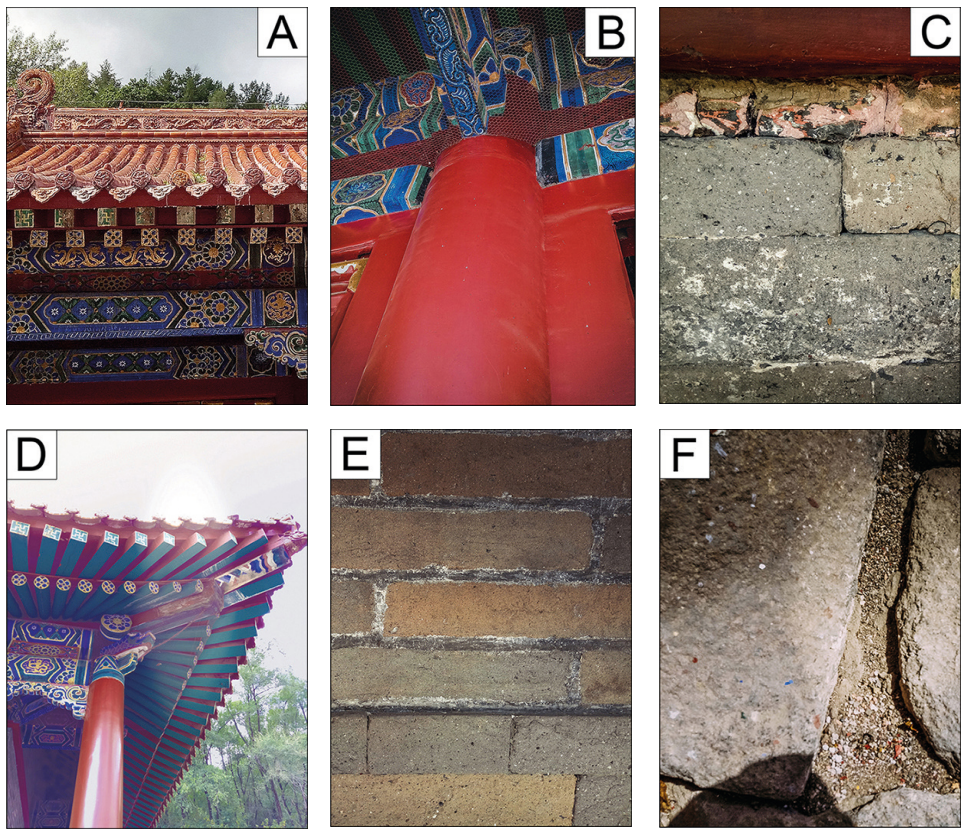

Figure 2 Present situation of Qiyun Hall (Source: Xiangyu Wang).

in the past resulted in a clear reduction in wind erosion of heritage buildings (Bitog et al. 2012; Gromke and Blocken 2015; Tong et al. 2016). Compared with traditional research methods, numerical simulations can provide an economic, intuitive, and reliable scientific basis for evaluating the health status of heritage buildings.

\section{Site Description}

\section{Conditions of Yongling Mausoleum}

Yongling Mausoleum was originally built in 1598. Ancestors of the first Qing emperor, Nurhachi (1559-1626) were buried in this tomb. They are Gaitemu, one of his ancestors, Fuman, his great-grandfather, Juechangan, his grandfather, and Takeshi, his father. The site covers an area of about $12,000 \mathrm{~km}^{2}$ creating impressive, luxuriant surroundings.

A field survey and investigation were conducted in September, 2018. The main buildings of the Yongling Mausoleum basically remain intact, but structural materials have been repaired several times, most of which were damaged from wind erosion. Damage has occurred in roofs, walls, columns, doors, windows, floors, foundations, and steps of the heritage buildings (Figure 1, Figure 2). 
Figure 3 Days with strong winds recorded each month for two years (Source: Xiaoyu Wang).

Figure 4 Geographical location of the Yongling Mausoleum and wind direction for the numerical simulation (the white structures form the model of the Yongling Mausoleum) (Source: Xiaoyu Wang).
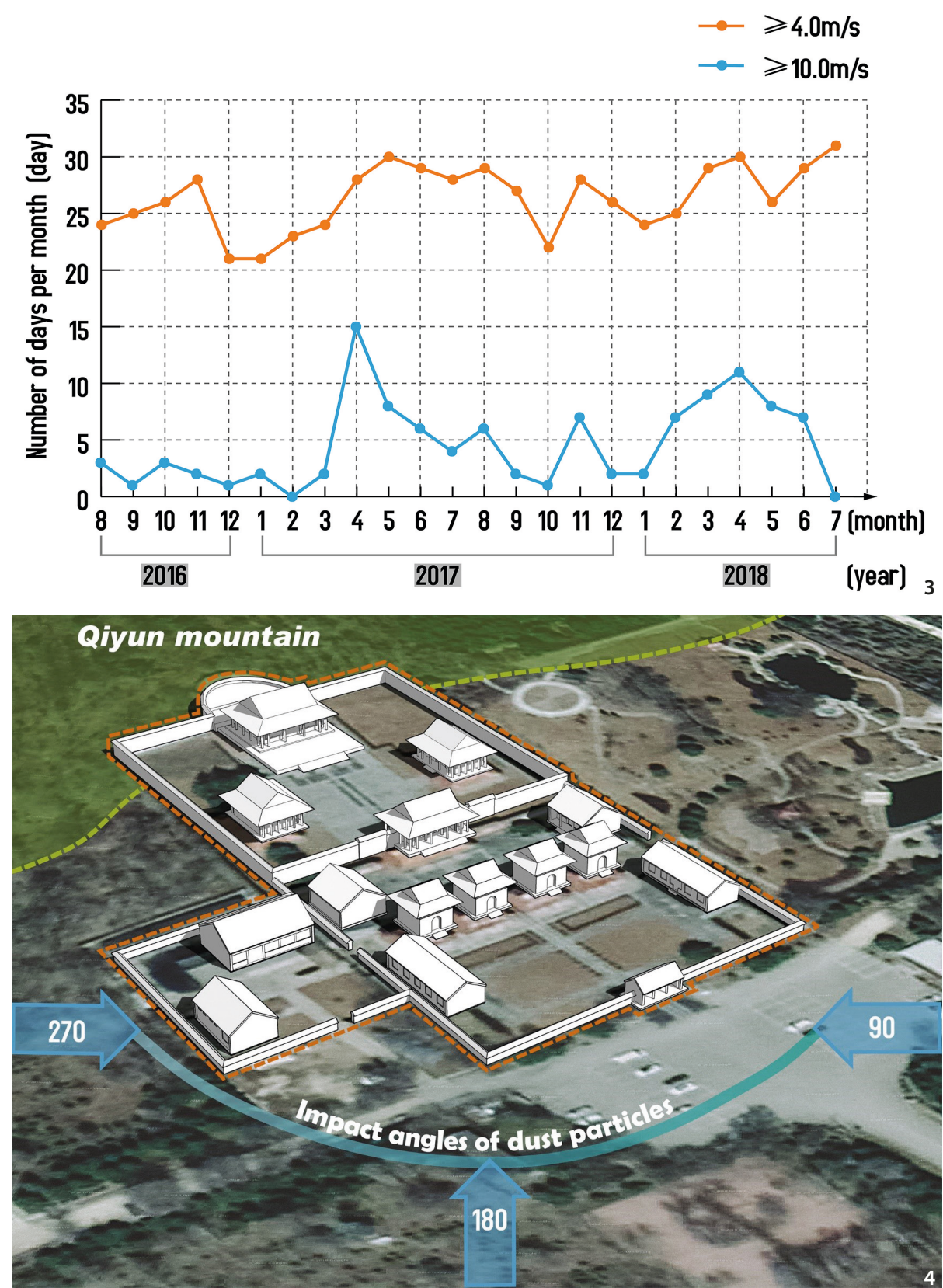

\section{Wind Characterisation}

Windy weather carrying sand and dust is very harmful to heritage buildings. To determine the wind speed and direction for simulations, actual wind conditions at the location needs to be known. The dust originates mainly from the Loess Plateau and Horqin Dust Land, which are located in the northern and western regions of Liaoning Province. Yongling Town $\left(40^{\circ} 31^{\prime}-41^{\circ} 50^{\prime} \mathrm{N}, 124^{\circ} 41^{\prime}-\right.$ $125^{\circ} 05^{\prime} \mathrm{E}$ ) is located in the eastern region of Liaoning Province. It is under the jurisdiction of Xinbin Manchu Autonomous County, Fushun City. Because of its remote geographical location, China Meteorological Administration began collecting meteorological data (including air pressure, wind speed, wind direction, temperature, relative humidity, and rainfall) of Xinbin County from August of 2016. We utilised the hourly weather data from August 1, 2016 to July 31, 2018 that had been collected as our basic test data.

From the 17,421 hourly weather data that was analysed, the average wind speed is $3.5 \mathrm{~m} / \mathrm{s}$ annually. The maximum wind speed reached was $28.9 \mathrm{~m} / \mathrm{s}$, and the number of days with wind speeds over $4 \mathrm{~m} / \mathrm{s}$ (3329 hourly weather data) was 633 , accounting for $86.7 \%$ of the two year period. The number of days with wind speeds over $10 \mathrm{~m} / \mathrm{s}$ (249 hourly weather data) was 109 , accounting for $14.9 \%$ for that period (Figure 3). Southerly wind directions $\left(90^{\circ}-270^{\circ}\right)$ 
with wind speeds of over $10 \mathrm{~m} / \mathrm{s}$ prevailed in summer, representing a large $47.9 \%$ over the period (Figure 4 ).

In regard to the wind boundary layer over the terrain, the velocity profile specifying the inlet boundary condition for each simulation was defined according to this well-established equation (Hanna and Hosker, 1982),

$$
U_{z}=U_{10}\left(\frac{z}{10}\right)^{n_{p}}
$$

where $U_{z}$ denotes the air velocity which depends on height $\mathrm{z}, \mathrm{U}_{10}$ the air velocity at the height of $10 \mathrm{~m}$ (assumed to be 4 or $10 \mathrm{~m} / \mathrm{s}$ ), and $n_{p}$ an exponent (called the Hellman exponent) that depends on the atmospheric stability and the nature of the terrain (Blocken, Roels and Carmeliet 2007; Langenbach 2007; Kaltschmitt Martin and Wise 2007). The value for $n_{p}$ at locations near the suburbs of the city is assumed to be 0.22 (Kaltschmitt and Wise, 2007). The boundary conditions were located far enough from the site so that the flow field is allowed to develop in accordance with terrain features, which also induce wind flow modifications that need to be resolved by the CFD solver.

\section{CFD setup}

\section{RNG $k-\varepsilon$ Model}

In our study, we used the RNG $k-\varepsilon$ model for viscous modelling. The RNG $k-\varepsilon$ model was proposed in Orszag and Yakhot (1986). Although similar in form to the standard $k-\varepsilon$ model, the RNG $k-\varepsilon$ model is more accurate and reliable for a wider class of flows than the standard $k-\varepsilon$ model (Orszag et al. 1993). The turbulence kinetic energy, and its rate of dissipation, $\varepsilon$, are obtained from the following transport equations (ANSYS 2015), for which $G_{k}$ and $G_{b}$ represent the turbulence kinetic energy generated from the mean velocity gradient and buoyancy, respectively, $Y_{M}$ represents the contribution of the fluctuating dilatation in compressible turbulence to the overall dissipation rate, $\alpha_{k}$ and $\alpha_{\varepsilon}$ denote the inverse effective Prandtl numbers for $k$ and $\varepsilon$, respectively. And $S_{k}$ and $S \varepsilon$ are user-defined source terms.

\section{Geometry and Mesh Generation}

A detailed geometrical model of the Yongling Mausoleum was generated by using ANSYS Workbench software. The model included important structural elements such as roofs, walls, doors, windows, columns, foundations, and floors of the 15 heritage buildings, but excluded features such as roof undulations, railings, and decorations. The computational domain follows the more conservative recommendations (Blocken, 2015) and its size was determined as $900 \times 900 \times 80 \mathrm{~m}^{3}\left(\mathrm{~L} \times \mathrm{W} \times \mathrm{H}_{\text {domain }}\right)$. After the model was developed, a mesh was generated for it using ANSYS ICEM software (Figure 5a, Figure 5b). The mesh contained 13.13 million tetrahedral elements and included appropriate mesh refinements near the locations of interest where particles were expected to travel. The minimum, average, and maximum cell length scales in the mesh were $0.2 \mathrm{~m}$ (at the boundary layer of the buildings), $0.6 \mathrm{~m}$, and $5.0 \mathrm{~m}$ (at the top of the domain far from the buildings). The first cell node at the boundary layer was located $0.005 \mathrm{~m}$ away from the wall, resulting in $\mathrm{y}^{+}$values between 30 and 300 , which were adequate for the automatic wall functions used in the RNG $k-\varepsilon$ model (We used only tetrahedral elements without the unnecessary prismatic elements on the walls to improve the boundary layer resolution. This is a drawback of the mesh used).

To verify mesh independence, we took measurements at a single point for each of the four buildings at a height of $6 \mathrm{~m}$ (Figure 6). Changing the number of elements in

$$
\frac{\partial}{\partial t}(\rho k)+\frac{\partial}{\partial x_{i}}\left(\rho k u_{i}\right)=\frac{\partial}{\partial x_{j}}\left(\alpha_{k} \mu_{e f f} \frac{\partial k}{\partial x_{j}}\right)+G_{k}+G_{b}-\rho \varepsilon-Y_{M}+S_{k}
$$

and

$$
\frac{\partial}{\partial t}(\rho \varepsilon)+\frac{\partial}{\partial x_{i}}\left(\rho \varepsilon u_{i}\right)=\frac{\partial}{\partial x_{j}}\left(\alpha_{\varepsilon} \mu_{e f f} \frac{\partial \varepsilon}{\partial x_{j}}\right)+C_{1 \varepsilon} \frac{\varepsilon}{k}\left(G_{k}+C_{3 \varepsilon} G_{b}\right)-C_{2 \varepsilon} \rho \frac{\varepsilon^{2}}{k}-R_{\varepsilon}+S_{\varepsilon}
$$



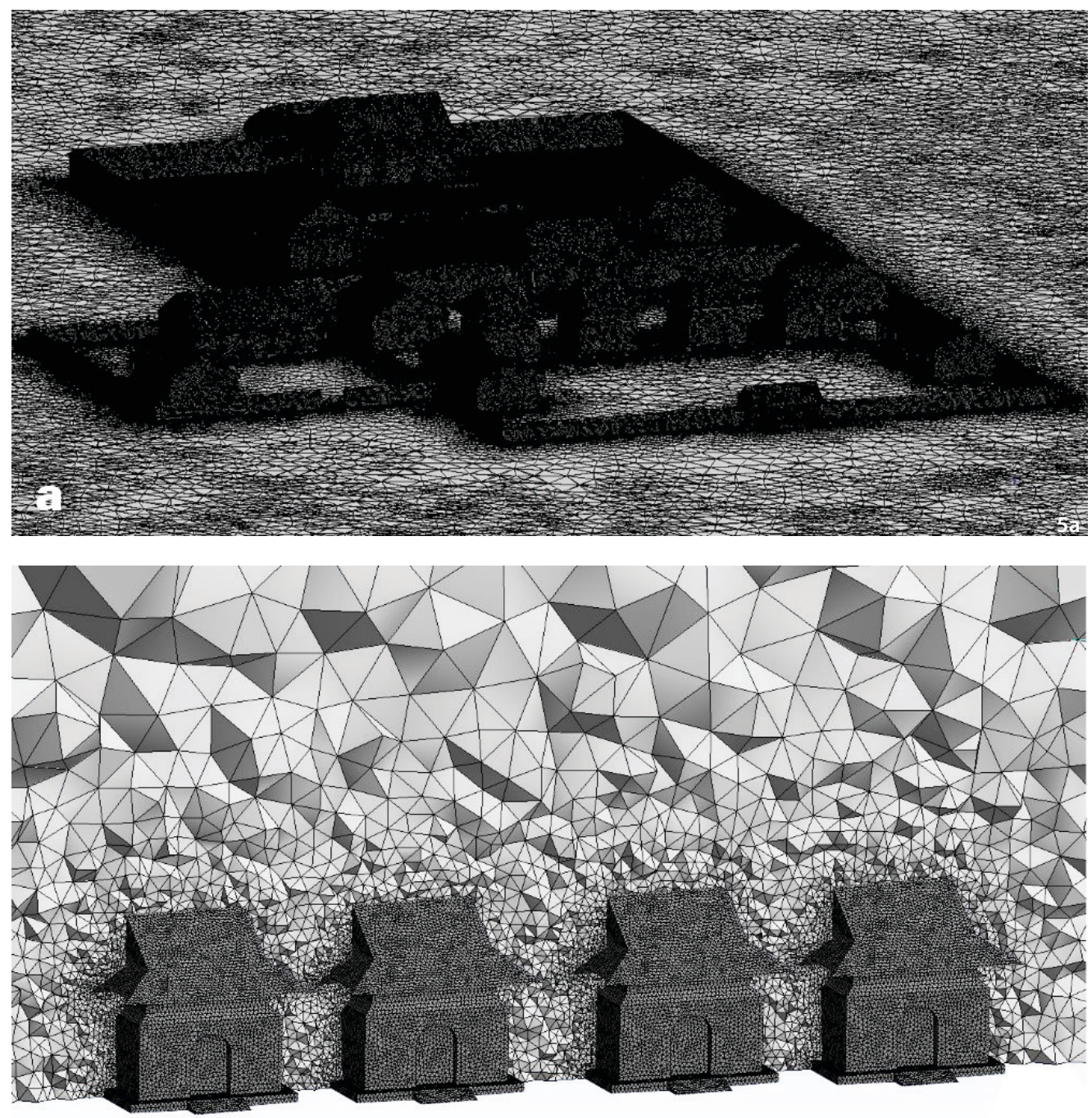

\section{b}

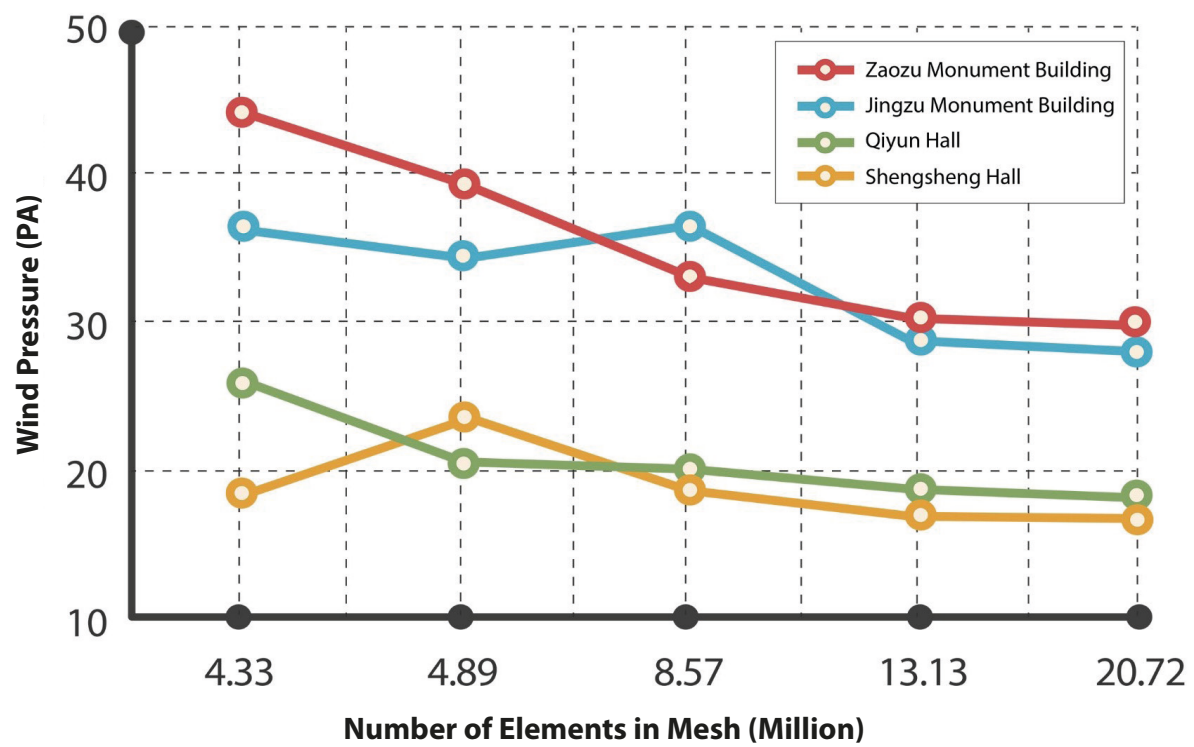

Figure 5a View of the computational domain (geometry and mesh) for the Yongling Mausoleum (Source: Xiaoyu Wang).

Figure $5 \mathrm{~b}$ Details of the mesh refinement with tetrahedral elements at the boundary layer of buildings (Source: Xiaoyu Wang). Figure 6 Mesh-independence verification result (Source: Xiaoyu Wang). 

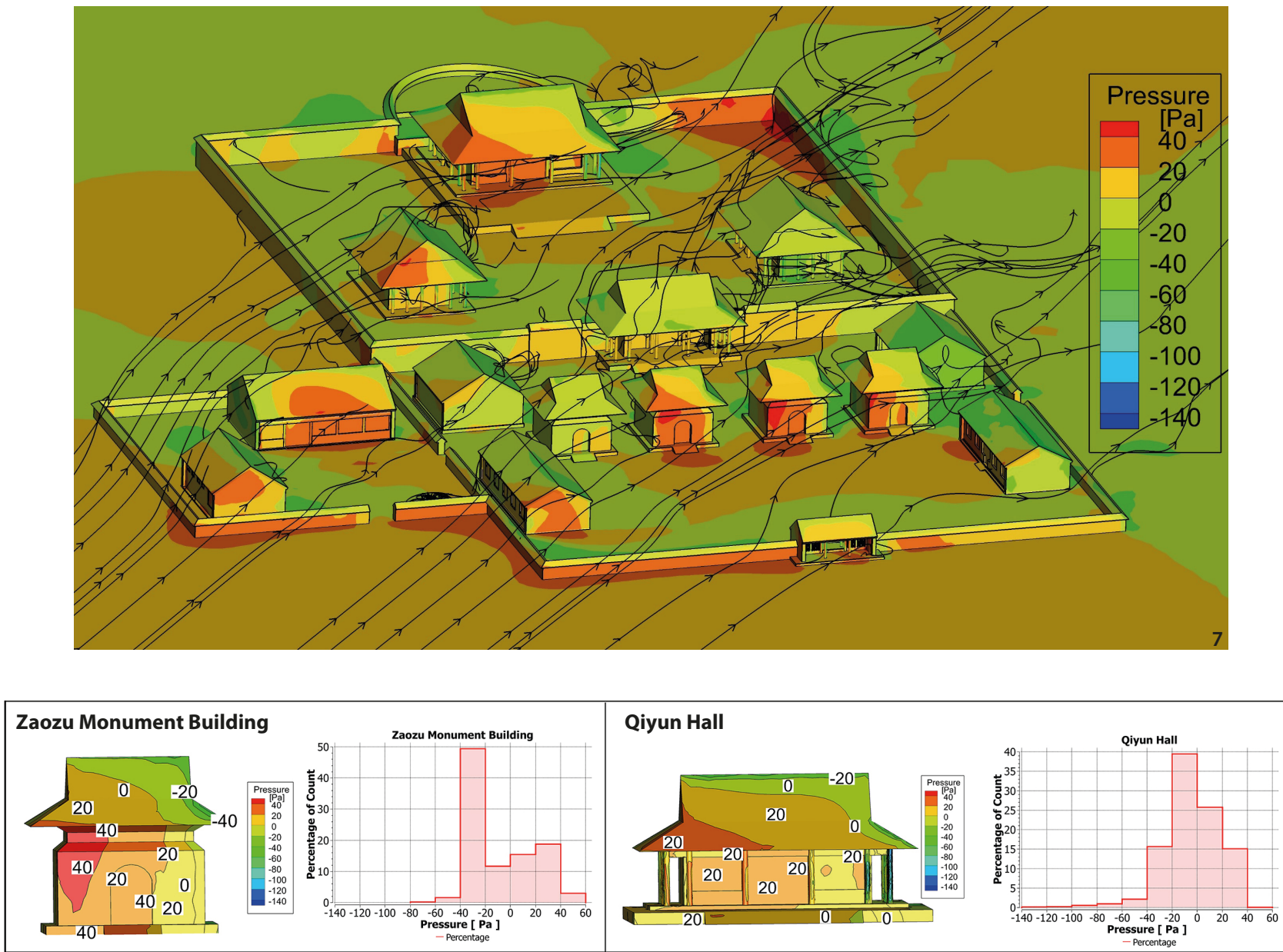

Jingzu Monument Building

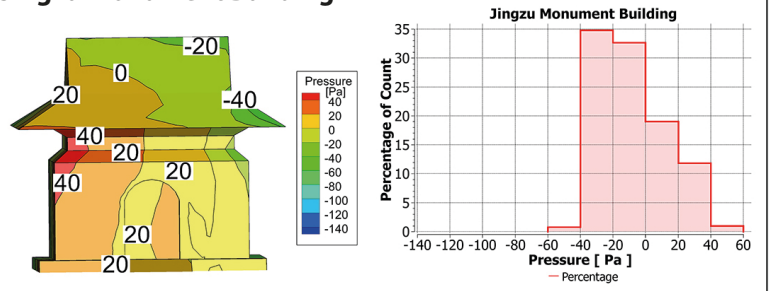

\section{Shengsheng Hall}

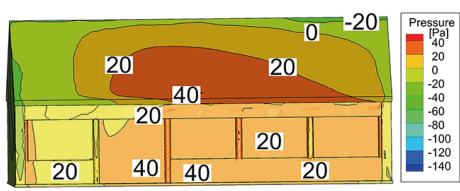

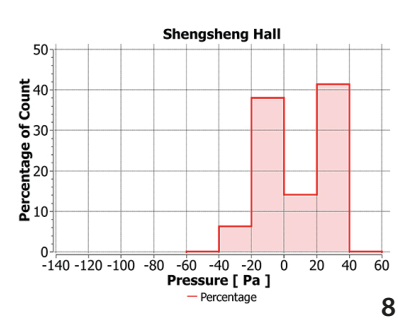

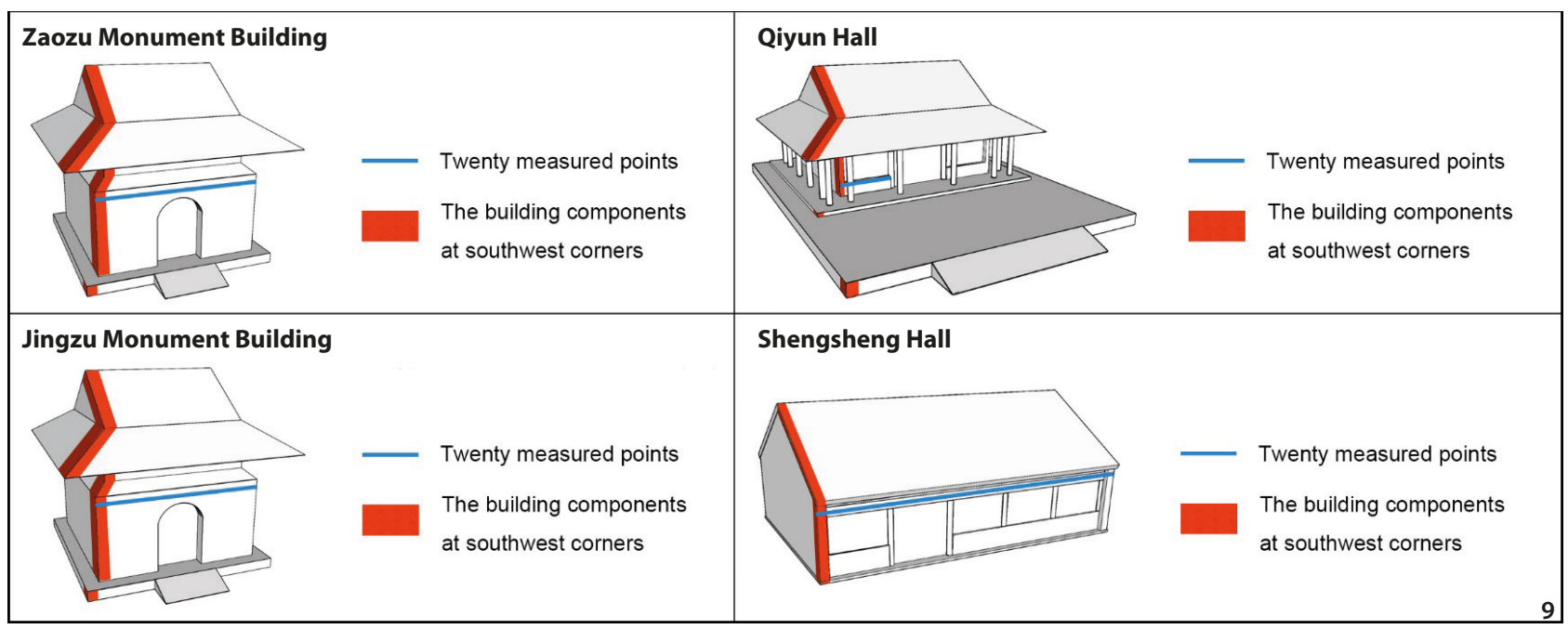

Figure 7 Wind pressure and particle streamlines above Yongling Mausoleum before greening (Source: Xiaoyu Wang). Figure 8 Wind pressure (static pressure) and diagrams for four buildings before greening (Source: Xiaoyu Wang). Figure 9 Sites of the 20 measured points on southwest-facing corners (Source: Xiaoyu Wang). 

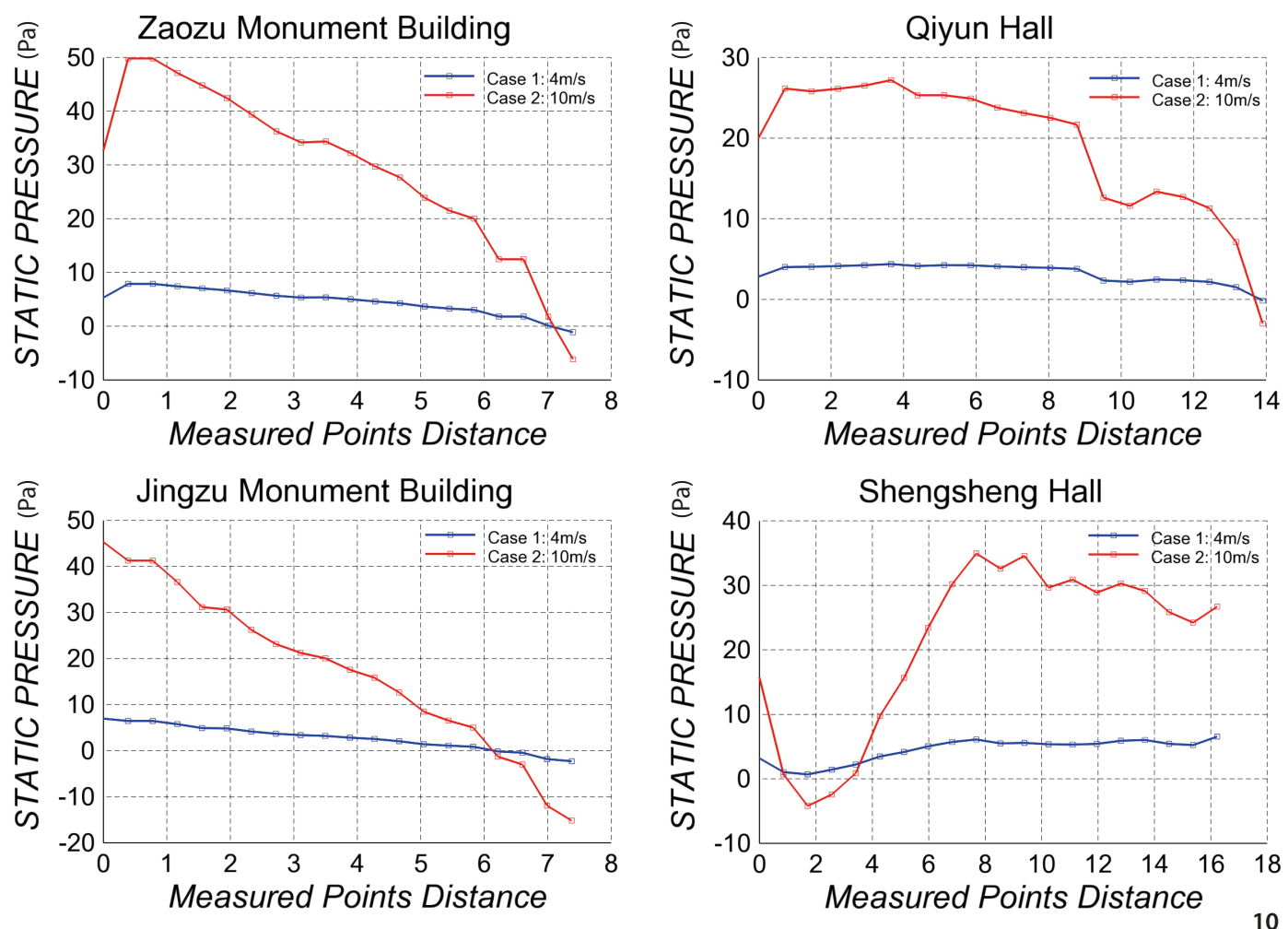

Figure 10 Wind pressure on building structures at southwest-facing corners before greening (Source: Xiaoyu Wang).

the mesh from 13.13 million to 20.72 million changed the wind pressure values only slightly. A refinement of the mesh (the addition of more elements) had little impact on the calculation results and therefore the mesh of 13.13 million elements was adopted.

The simulations were performed by using ANSYS Fluent software, the word length for all computations being double precision. The dust particle diameter, $d_{p}$, was set at $0.001 \mathrm{~m}$, the flow rate, $f$, at $1 \mathrm{~kg} / \mathrm{s}$ (Dong, Liu and $\mathrm{He}$ 1995), the particle density, $\rho_{p}$, at $1500 \mathrm{~kg} / \mathrm{m}^{3}$, and the relative particle velocity, $v$, was defined as $\mathrm{v} \_$particle - v_wind. The velocity-inlet boundary condition was set to that of the inlet, the turbulent intensity $I$ to $5 \%$, the hydraulic diameter $D_{H}$ to $6.667 \mathrm{~m}$, and the velocity magnitude $u_{\text {avg }}$ was defined as a user-defined function in the program environment. Pressure-outlet was set as to the outlet boundary condition. The boundary conditions for the southwest surfaces and grounds of the buildings were set as walls without slip. The fluid flow converged in 500 iterations with equation-normalised residuals of $<0.001$ to ensure convergence was achieved. The methods of solution chosen to calculate the results were the pressurevelocity coupling, segregated-solver, and second-order upwind methods.

\section{Results and Discussion}

\section{Analysis of Results before Greening}

To assess the damage and recovery to the heritage buildings, wind pressure and particle streamlines were generated for the Yongling Mausoleum before greening (Figure 7) as a reference. Figure 8 presents static wind pressure and diagrams for the four buildings before greening. Figures 9-16 present the average wind pressure from 20 measured points for the four buildings. When wind speeds reached $10 \mathrm{~m} / \mathrm{s}$, the average wind pressure was 10-40 Pa more than that for wind speeds of $4 \mathrm{~m} / \mathrm{s}$. Because of limitations of space, we selected only representative results of the four heritage buildings for analysis.

1. The building structures in the southwest-facing corners were eroded more severely by wind. 20 measurement points were chosen at various locations $(4.0 \mathrm{~m}$ height above the ground) on the south-facing surfaces of four buildings (Figure 9). Wind pressures (Figure 10) were greater when the wind impacted building structures in the southwest-facing corners. When wind speeds reached $10 \mathrm{~m} / \mathrm{s}$, the average wind pressure on the building structures of the Zaozu Monument was 55.97 Pa greater than for the others; similarly, the average wind pressures on the southwest-facing structures of Jingzu Monument, Qiyun Hall, and Shengsheng Hall 

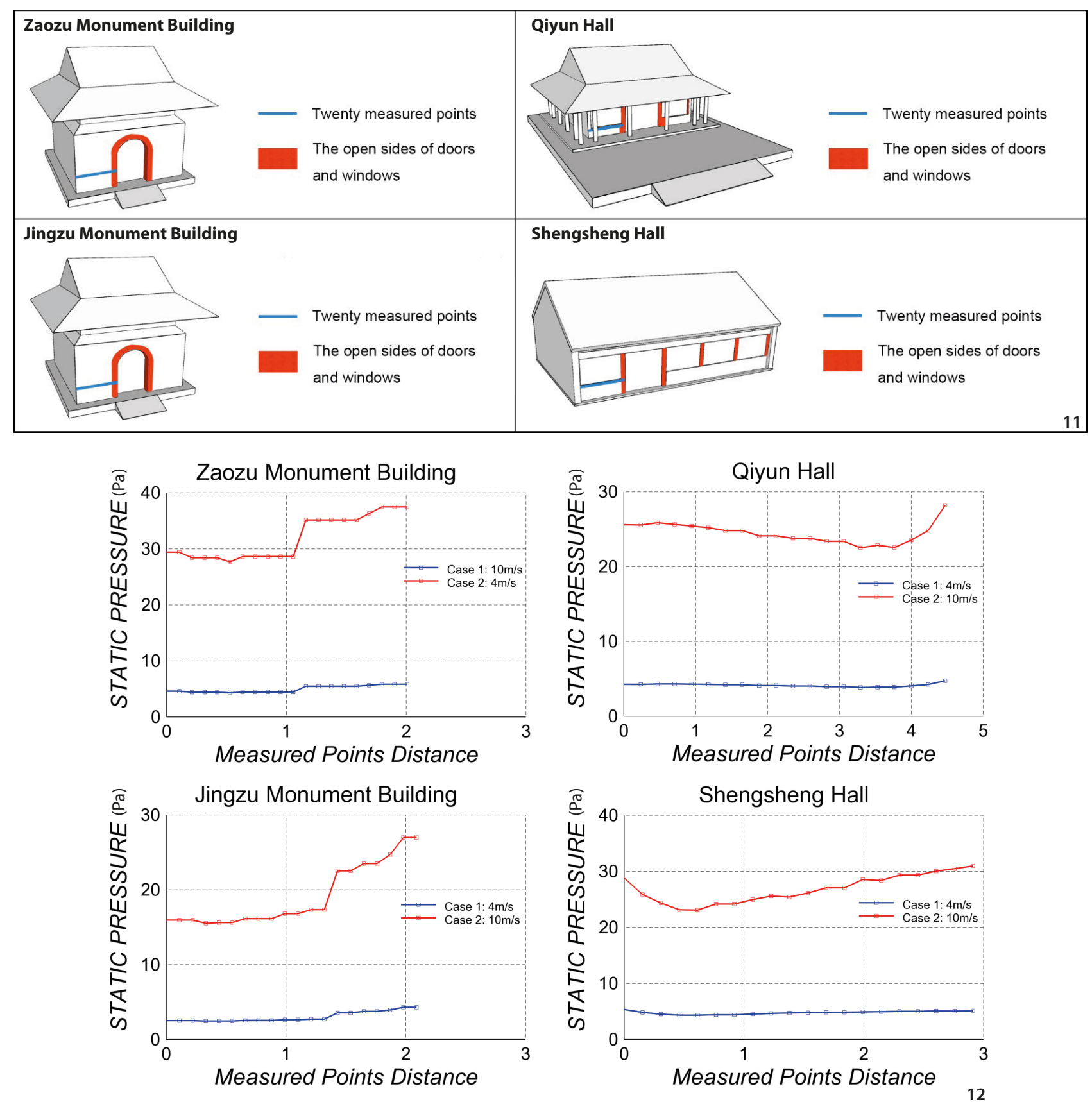

Figure 11 Sites of the 20 measured points near the doors and windows (Source: Xiaoyu Wang).

Figure 12 Wind pressure near the frames of doors and windows before greening (Source: Xiaoyu Wang).

were respectively 60.45 $\mathrm{Pa}, 30.20 \mathrm{~Pa}$, and 39.14 Pa more than for the other buildings.

2. The exterior-facing sides of doors and windows were also eroded severely. Sites for 20 measurement points were chosen at locations ( $1.5 \mathrm{~m}$ height above ground) on south-facing surfaces of the four buildings (Figure 11). As seen in Figure 12, the wind pressure is greater near the outer frames of doors and windows. When wind speeds reached $10 \mathrm{~m} / \mathrm{s}$, the average wind pressure near the doors and windows at the Zaozu Monument were 9.81 Pa more than the others; similarly, the average wind pressure for the Jingzu Monument, the Qiyun Hall, and the Shengsheng Hall were respectively 11.47 $\mathrm{Pa}, 5.68 \mathrm{~Pa}$, and $7.88 \mathrm{~Pa}$ more than for others.

3. Places affected by swirling wind had also eroded severely. Such winds form at the intersections of walls, columns, stair wells, and floors of the heritage buildings. Sites of 20 measurement points were chosen on the ground along southwest-facing surfaces of the four buildings (Figure 13). The wind pressure at these points 

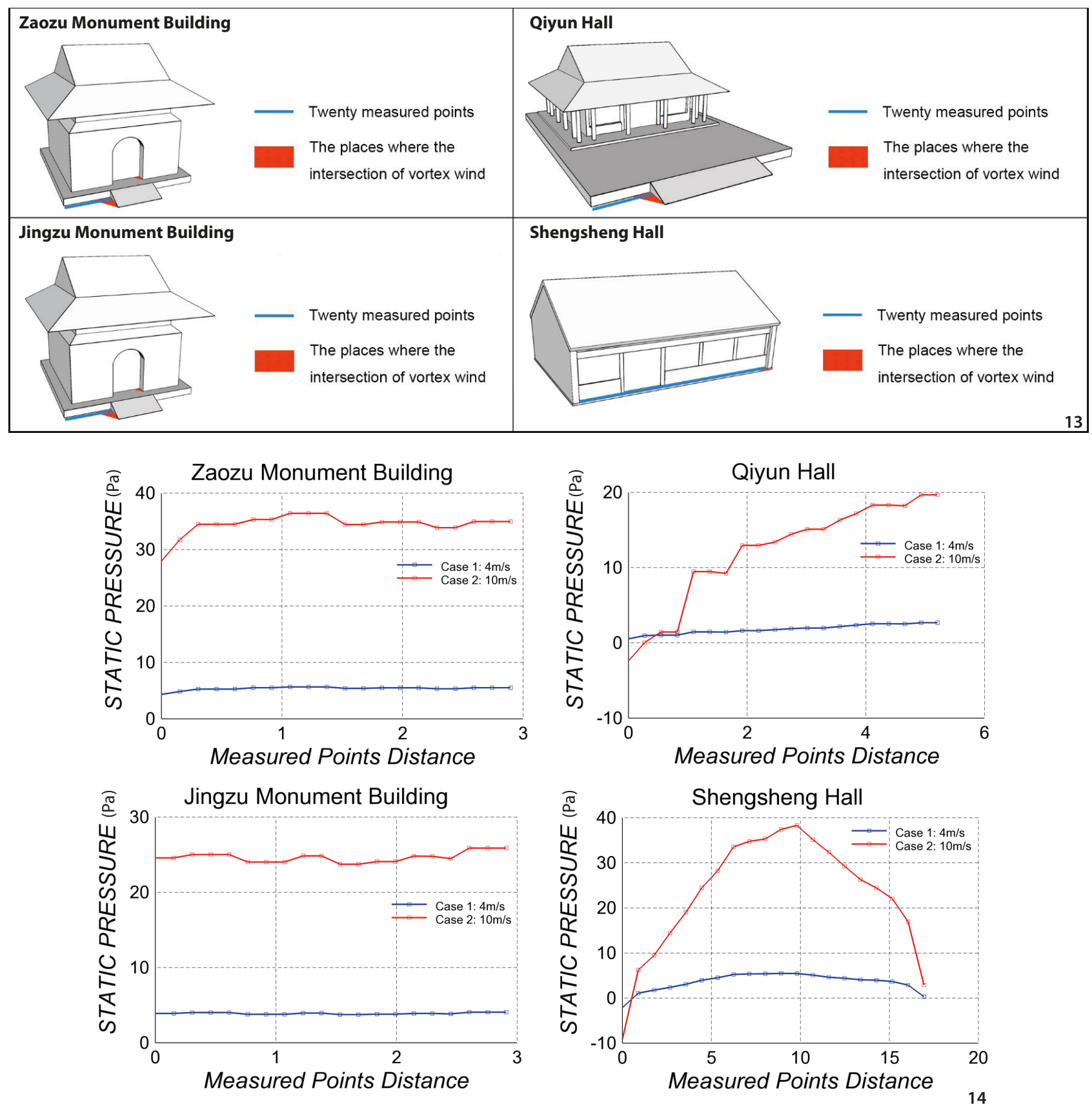

Figure 13 Sites of the 20 measured points at places affected by swirling wind (Source: Xiaoyu Wang).

Figure 14 Wind pressure near the frames of doors and windows before greening (Source: Xiaoyu Wang).

(Figure 14) was greater when swirling winds developed. When wind speeds reached $10 \mathrm{~m} / \mathrm{s}$, the average wind pressure at these places for the Zaozu Monument, the Jingzu Monument, Qiyun Hall and Shengsheng Hall were respectively $8.48 \mathrm{~Pa}, 2.15 \mathrm{~Pa}, 22.07 \mathrm{~Pa}$, and 47.47 Pa more than for other places.

4. The eaves of sloping roofs were also badly eroded by wind. Sites of twenty measurement points were chosen on the eaves of the four buildings (Figure 15). As evident in Figure 16, wind pressures were greater when the wind got under the eaves. When wind speeds reached $10 \mathrm{~m} / \mathrm{s}$, the average wind pressure on the eaves at the Zaozu Monument, Jingzu Monument, Qiyun Hall, and Shengsheng Hall were respectively $60.35 \mathrm{~Pa}, 60.20 \mathrm{~Pa}$, 23.22 Pa, and 35.45 Pa more than for other buildings.

\section{General Greening Plan}

Because of the severe erosion of some of the structural materials, we developed in the course of our research a greening plan for the Yongling Mausoleum. Through 

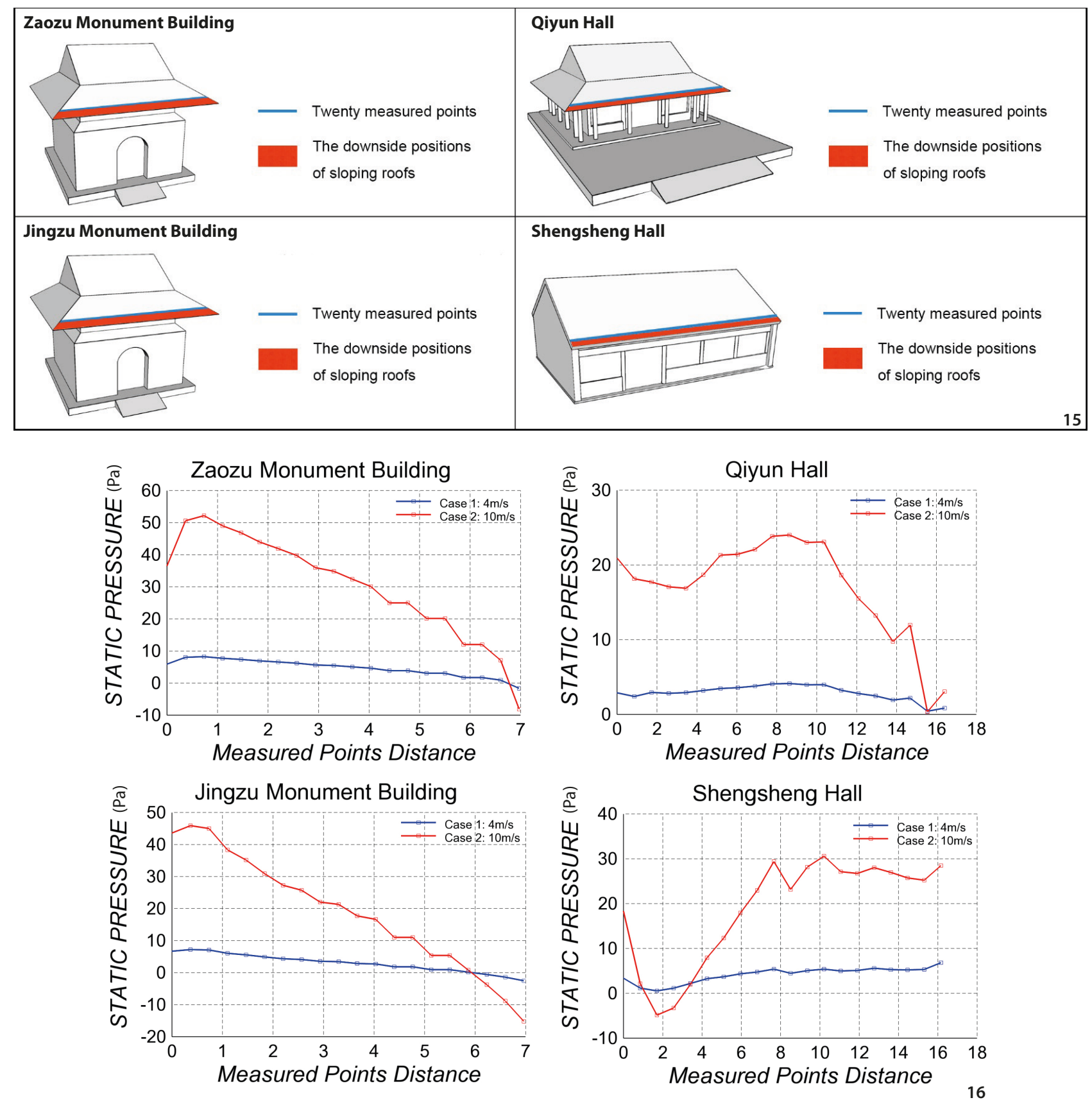

Figure 15 Site of the 20 measured points on the eaves of sloping roofs (Source: Xiaoyu Wang).

Figure 16 Wind pressure along the eaves of the sloping roofs, before greening (Source: Xiaoyu Wang).

suitable greening, tree species selection, and scientific planting methods, we believe that plants can exert their unique ecological and physical adaptions to provide better protection to heritage buildings and their historical environments (Figure 17).

1. Plant green vegetation. Planting trees is effective at reducing wind speeds and thereby slowing the effects of wind erosion. The airflow slows down rapidly due to friction with trunks, branches, and leaves shedding the air and particles of their kinetic energy when passing through the trees. About $48 \%$ of wind energy is estimated to be lost. Experiments show that areas within 5 to 10 times the height of a tree benefit best from the screening of trees (AIJ 2006).

2. Plant windbreak green turfs (Ji et al. 2015). Turf grasses also disperse the momentum of wind within a certain height from the ground and weaken the force of the wind near the surface. With greater vegetation coverage, the average wind speed near the surface is reduced significantly; moreover, turf grasses covering the 


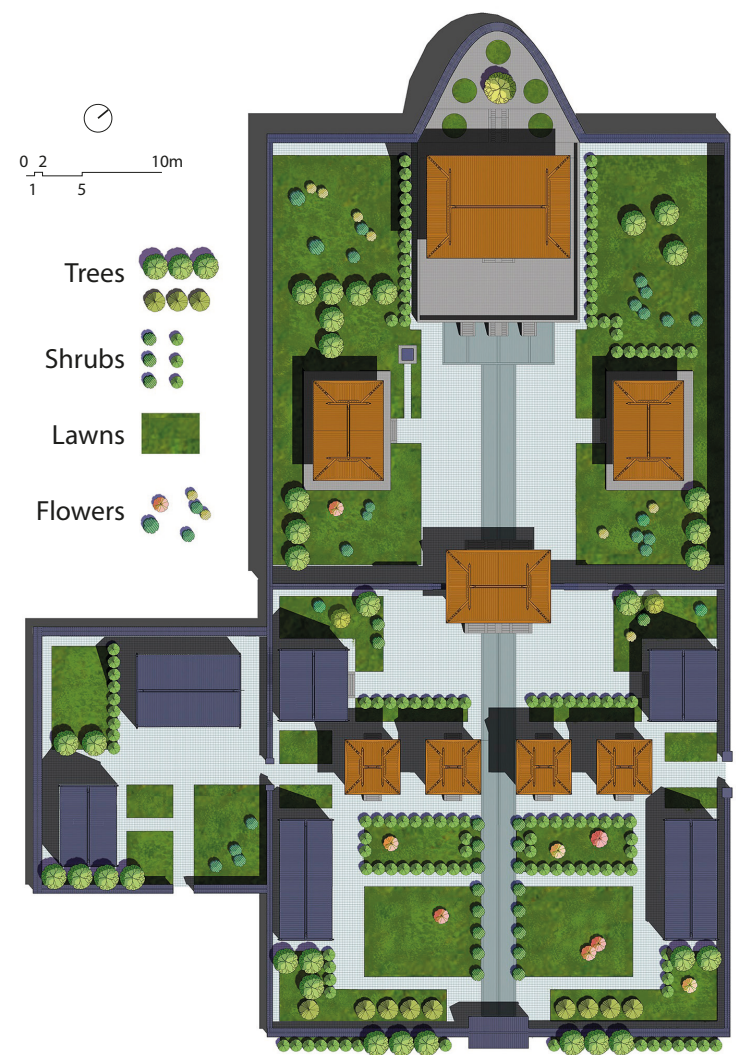

17

Figure 17 General greening plan of the Yongling Mausoleum (Source: Xiaoyu Wang).

surface can suppress directly surface soil depletion by strong airflows, and, therefore, as the vegetation coverage expands, the critical wind speed needed to lift up dust is increased significantly.

3. Plant trees and shrubs in rows (Xiao and Sun 2016). The effect of a windbreak is very significant when the density of planted trees in rows reach a threshold. Wind has difficulty passing through high-density vegetation. Large trees were planted on the south side of Zhenghong Gate, Qiyun Gate, and Shengsheng Hall and within the courtyard walls, with row spacing being 5-8 m. Medium and small-sized trees were planted on the north side of Zhenghong Gate and on the south side of Qiyun Gate, with row spacing being 3-5 m. Large shrubs were planted on both sides of the main road to the front courtyard, with row spacing of $2-3 \mathrm{~m}$. Small shrubs were planted on the south side of the Diqi and Qiban buildings, on the north and south sides of the four tomb buildings, the east and west sides of Qiyun Hall, and the west side of Guo House, with row spacing of 1-2 $\mathrm{m}$. The row pattern used in planting promoted a strong wind-breaking effect.

4. Select suitable tree crown size and height. For greening, the trees selected were those with neatly-shaped crowns (diameter $>5 \mathrm{~m}$ ). The best wind barriers on the leeward side of the heritage buildings attained decreases of about $35 \%$ in wind speed. The weakening of wind speed is also related to the density of trees. If the crown density is as much as $60 \%$ and the shrub density is about $50 \%$, a better wind barrier is achieved (Hong and Luo 2015).

5. Select tree species for reducing wind speed. Windbreaking effectiveness depends on the type and shape of trees. Although trees can withstand stresses imposed by the wind speed, the efficiency of resistance decreases at high wind speeds because of the streamlining of branches and leaves. Trees lose the capacity to reduce wind speed after their leaves have fallen off in autumn and winter; therefore, evergreen trees such as pine and cypress are recommended. The dominant species here are the Korean pine and evergreen trees, which can reach a height of $40 \mathrm{~m}$ and thus provide a strong windbreak.

6. Analysis of landscape and line of sight. To see the main heritage buildings at the Yongling Mausoleum better, we planted shrubs and lawns rather than trees in front of seven buildings (four monument buildings in the front courtyard and three hall buildings in Fangcheng). This ensures that the space is open enough to avoid the trees blocking the view (Figure 18).

\section{Analysis of Results after Greening}

After greening, the erosion severity for most of the heritage buildings at the Yongling Mausoleum lessened through wind-speed reduction. Figure 19 presents the wind pressure and particle streamlines at the Yongling Mausoleum after greening. Figure 20 presents the wind pressure (static pressure) and diagrams for the four

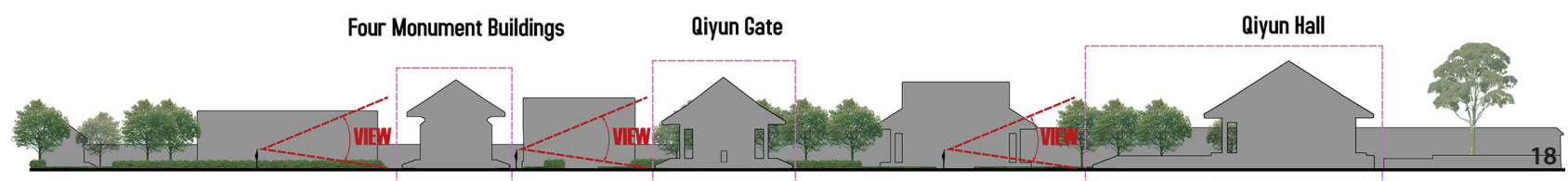

Figure 18 Analysis of landscape and line of sight (Source: Xiaoyu Wang). 

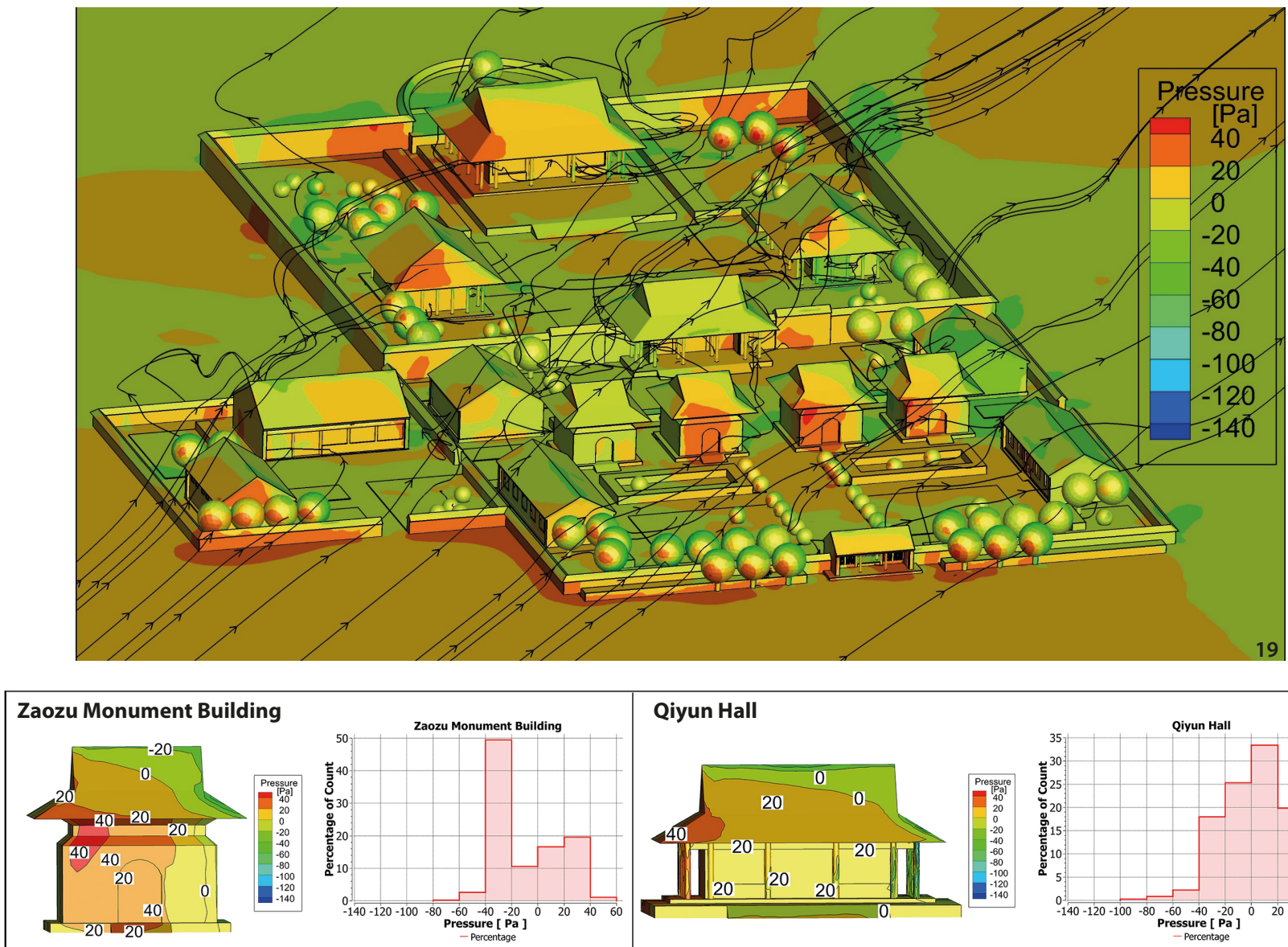

\section{Jingzu Monument Building}
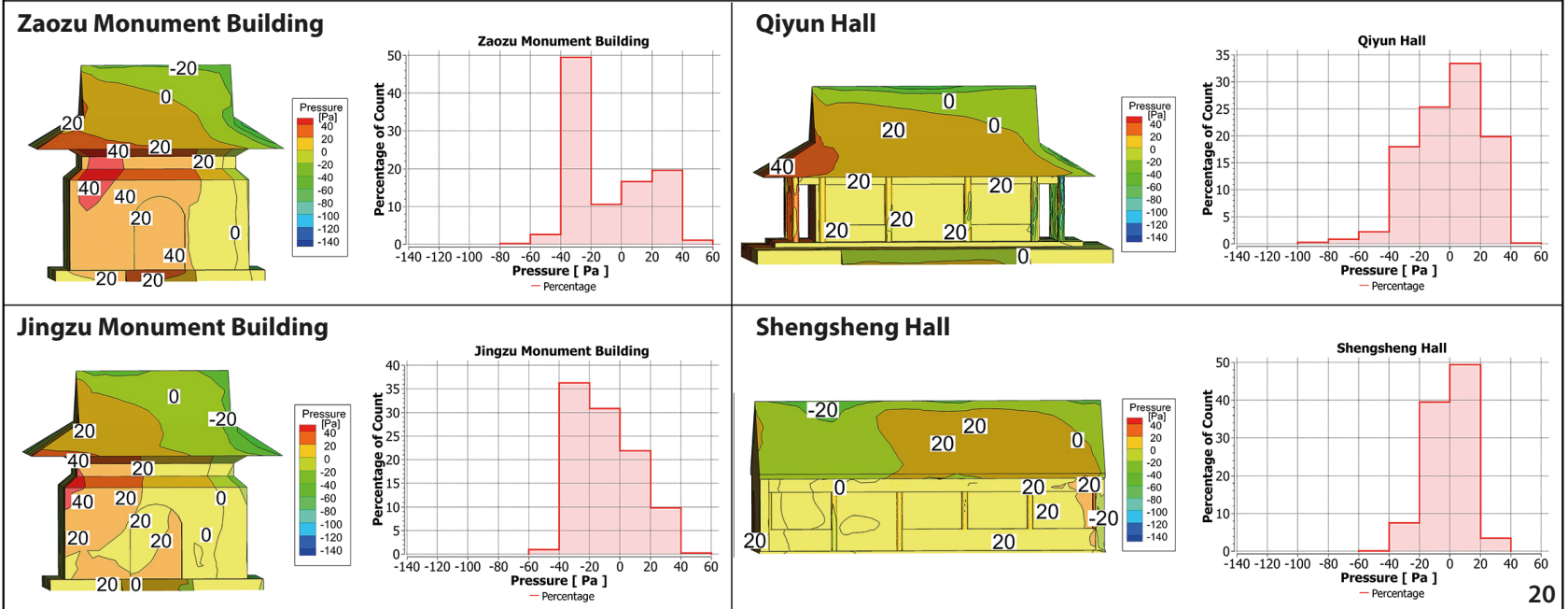

Shengsheng Hall
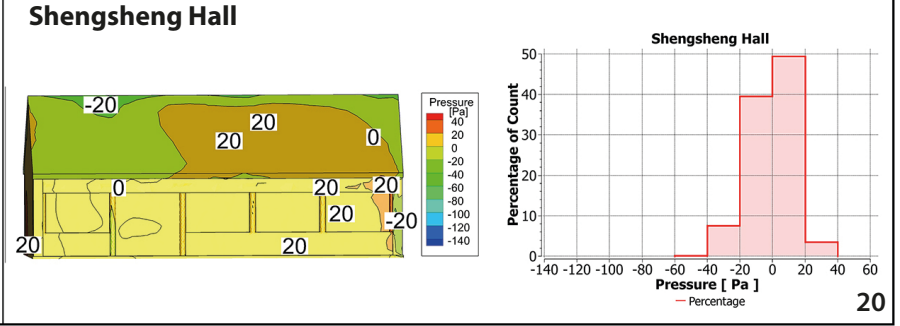

Figure 19 Wind pressure and particle streamlines at Yongling Mausoleum, after greening (Source: Xiaoyu Wang).

Figure 20 Wind pressure (static pressure) and diagrams for four buildings, after greening (Source: Xiaoyu Wang).

buildings after greening. High wind pressures of 40-60 $\mathrm{Pa}$ at the Zaozu Monument Building were reduced by $1.90 \mathrm{~Pa}$ after greening; similar results were recorded at other sites after greening: at the Jingzu Monument Building, pressures of 20-40 Pa were reduced by $2.05 \mathrm{~Pa}$; at Qiyun Hall, pressures of 20-40 Pa were reduced by 4.76 Pa; and at Shengsheng Hall, pressures of 20-40 Pa were reduced by $37.92 \mathrm{~Pa}$. Figure 21 to 24 present the average wind pressure at the twenty measured points for the four sites. The simulation results showed that the severity of wind erosion was governed by the density of trees. There were few trees in front of the Zaozu and the Jingzu Monument Buildings, and therefore, the average wind pressure had been reduced a little before greening.
1. After greening, the severity of wind erosion damage to the building structures at southwest-facing corners diminished. Data were recorded from the twenty measurement points chosen at locations (at $4.0 \mathrm{~m}$ height above the ground) on the south-facing surfaces of the four buildings (Figure 9). Looking at Figure 21, we can see that when wind speeds had clearly reached $10 \mathrm{~m} / \mathrm{s}$, the average wind pressure on structures at southwest-facing corners of the Zaozu Monument Building weakened by $1.93 \mathrm{~Pa}$ (6.5\% of that before greening); similarly, the average wind pressure on corresponding surfaces of the Jingzu Monument Building, Qiyun Hall, and Shengsheng Hall had fallen by 0.41 $\mathrm{Pa}$ (2.4\%), 9.21 Pa (4.8\%), and 9.29 Pa (71.7\%), the percentages being relative to pressures before greening. 

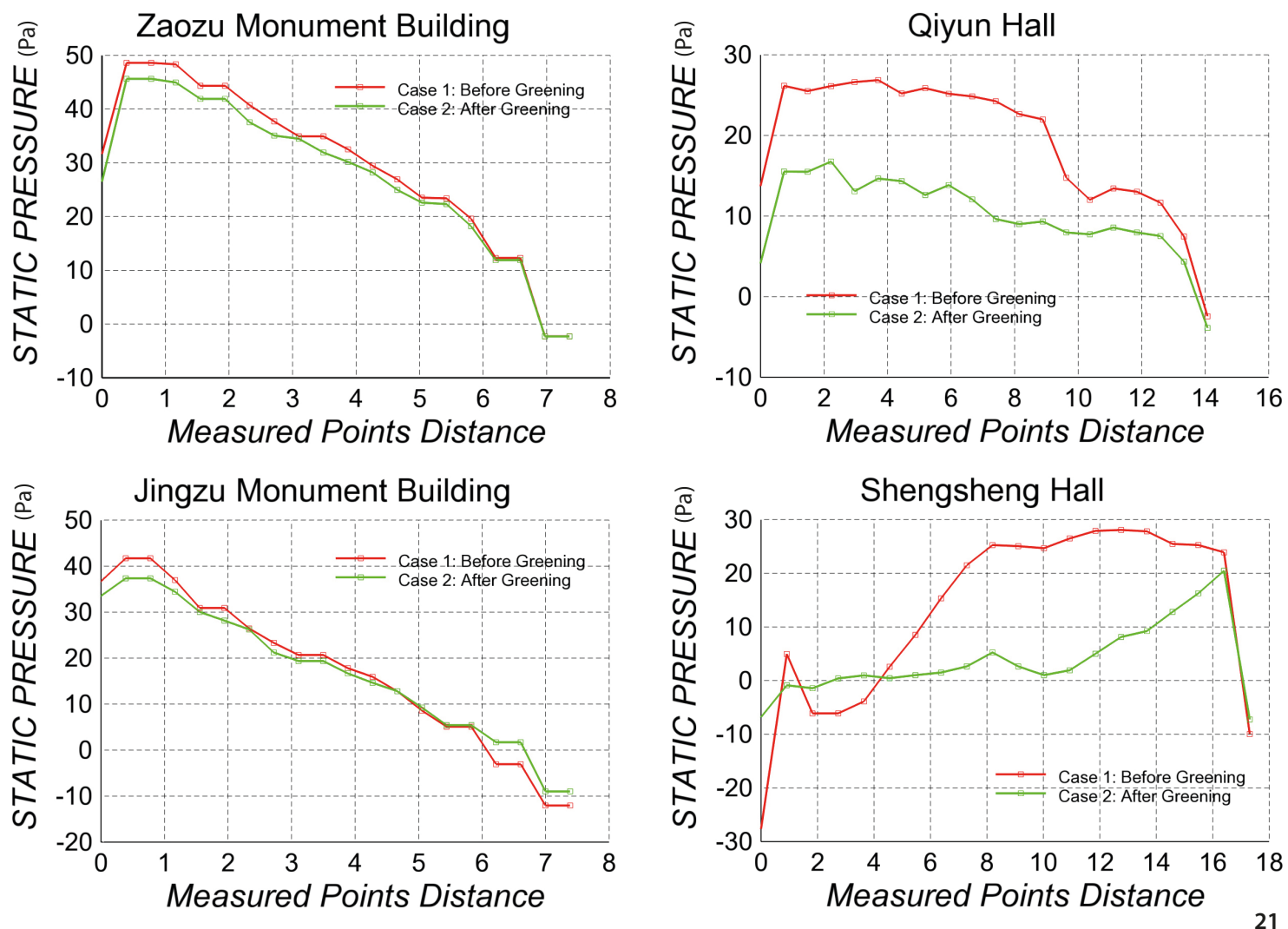

Figure 21 Wind pressure on building structures at southwest-facing corners, after greening (Source: Xiaoyu Wang).
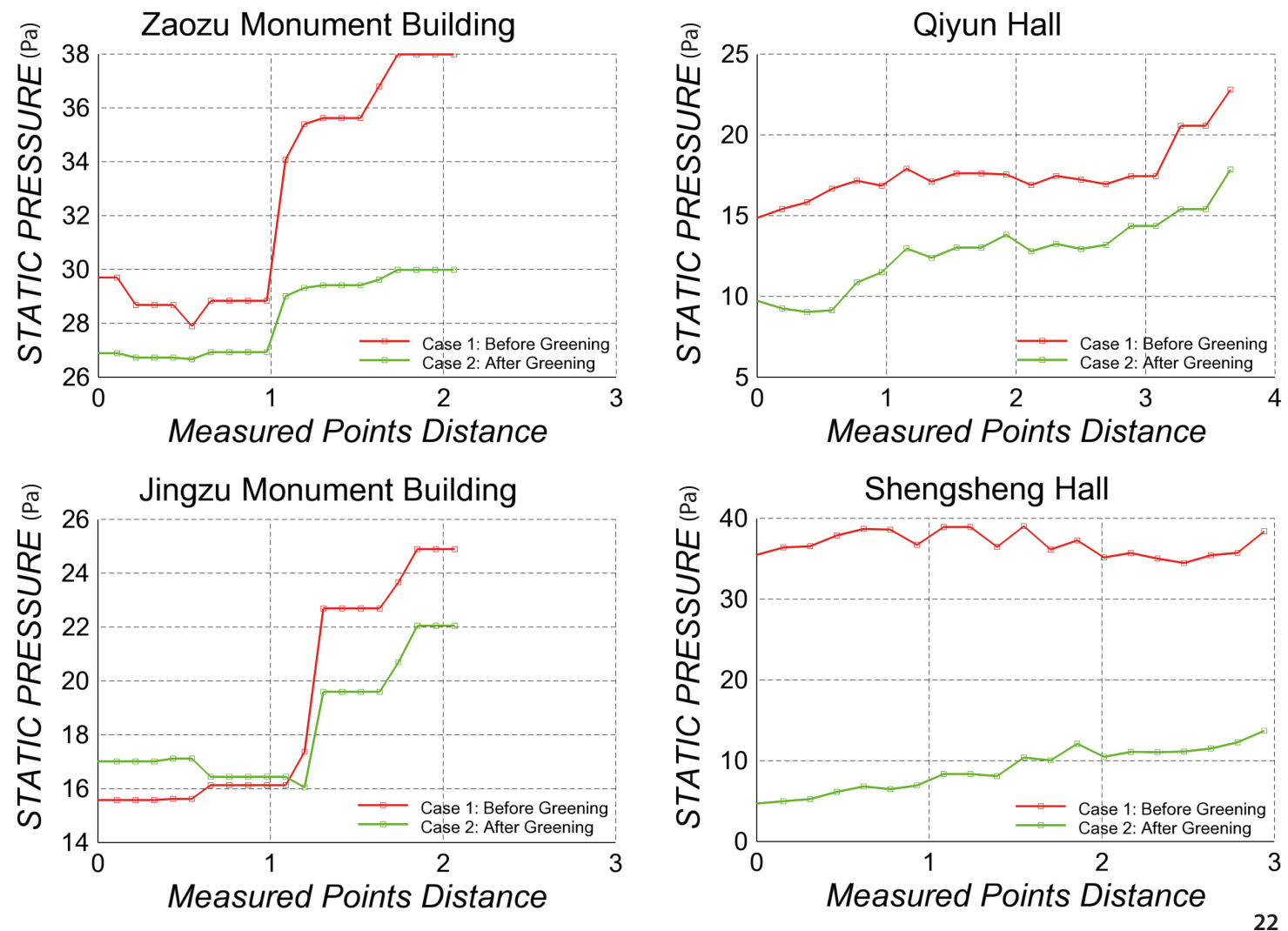

Figure 22 Wind pressure on the outside of doors and windows, after greening (Source: Xiaoyu Wang). 
2. After greening, the severity of the eroded exterior surfaces around doors and windows had diminished. Data were recorded from the twenty measurement points chosen at locations (1.5 m height above the ground) on the south-facing surfaces of the four buildings (Figure 11). In Figure 22, when the wind speed reached $10 \mathrm{~m} /$ $s$, the average wind pressure on the doors and windows of the Zaozu Monument Building had clearly fallen by 4.46 Pa (i.e., $13.6 \%$ of that before greening); similarly, for the Jingzu Monument Building, Qiyun Hall, and Shengsheng Hall, absolute (percentage) reductions of 0.75 Pa (3.9\%), 4.88 Pa (27.7\%), and 27.85 Pa (75.6\%), respectively, were obtained when measured against pre-greening calculations.

3. After greening, the erosion severity at places where swirling winds developed had diminished. Data recorded from the 20 measurement points were chosen on the ground near southwest-facing surface intersections for the four buildings (Figure 13). In Figure 23, when wind speeds reached $10 \mathrm{~m} / \mathrm{s}$, the average wind pressure at these places at the Zaozu Monument Building were reduced by $2.06 \mathrm{~Pa}(12.2 \%)$ when compared with measurements before greening, whereas for the Jingzu Monument Building and Shengsheng Hall, they were reduced by $18.15 \mathrm{~Pa}$ (53.2\%) and $17.06 \mathrm{~Pa}$ (74.1\%), respectively, from recorded pressures before greening. For Qiyun Hall, the pressure was negative because swirling winds generated suction.

4. After greening, the severity of damage to the eaves was reduced. Data were recorded from the twenty measurement points chosen on the eaves of the four buildings (Figure 15). From Figure 24, when wind speeds reached $10 \mathrm{~m} / \mathrm{s}$, the average wind pressure on the eaves of the Zaozu Monument Building diminished by $1.07 \mathrm{~Pa}(5.8 \%)$ from that before greening; similarly, for the Jingzu Monument Building, Qiyun Hall, and Shengsheng Hall, absolute (percentage) reductions of 2.92 Pa (9.1\%), 7.07 Pa (44.1\%), and $13.58 \mathrm{~Pa}$ (64.5\%) respectively were obtained when measured against pregreening calculations.

\section{Model Experiment}

To verify the accuracy of the CFD simulation, we made a 1:500-scale model of the Yongling Mausoleum using a $3 \mathrm{D}$ printer. We used model dust to simulate the dust in air blown over the model. The wind speed was set at $1 \mathrm{~m} / \mathrm{s}$, and wind directions ranged from $90^{\circ}-270^{\circ}$ (north being $0^{\circ}$ ). The result showed that when wind flowed around the heritage buildings, it impacted with building surfaces. The surfaces of the modelled buildings affected by the wind were basically the same as those revealed in the numerical simulations. The density distribution of model dust accumulating on the building surfaces highlighted the areas where structures were severely affected by wind. They were the building structures at southwest-facing corners, the outer surfaces around doors and windows, places where swirling winds developed, and eaves of sloping roofs (Figure 25). To a certain extent, the qualitative analysis of the 1:500-scaled model experiment confirmed the accuracy of our simulation modelling and analysis.

\section{Conclusion}

Our CFD simulations have proved to be effective in investigating and predicting wind erosion over the four chosen heritage sites. With little previous work having been conducted on the Yongling Mausoleum in regard to wind erosion, our study sought to analyse the impact of geometri$\mathrm{cal}$ and computational parameters such as wind direction, wind pressure, and turbulence on heritage buildings using CFD. From the analyses performed, several conclusions were drawn:

1. Before greening, when wind speeds reached $10 \mathrm{~m} / \mathrm{s}$, the average wind pressure on key structures (those at southwest-facing corners, the exterior sides of doors and windows, places where swirling wind developed, and eaves of sloping roofs) of the four heritage buildings were 2.15-60.45 Pa more than that of other buildings.

2. With suitable greening, tree species selection, and scientific planting methods, the unique ecological performance of plants can be exploited to protect heritage buildings and their historical environments from wind damage.

3. After greening, the severity of damage to key structures of the four heritage buildings can be mitigated. When wind speeds reached $10 \mathrm{~m} / \mathrm{s}$, the average pressure on these key structures prone to erosion was diminished by $0.41-27.85 \mathrm{~Pa}$, representing $2.4-75.6 \%$ of the average pressure before greening. The simulation results showed that the severity of wind erosion correlates with the density of trees, rows of which can create a barrier against wind. There were several trees already in front of the buildings of the Zaozu Monument and the Jingzu Monument, so the average wind pressure was reduced a little before greening. The planting of more trees can protect these heritage sites from wind erosion.

We hope that our research is beneficial in highlighting a simple but timely prevention and reinforcement measure 

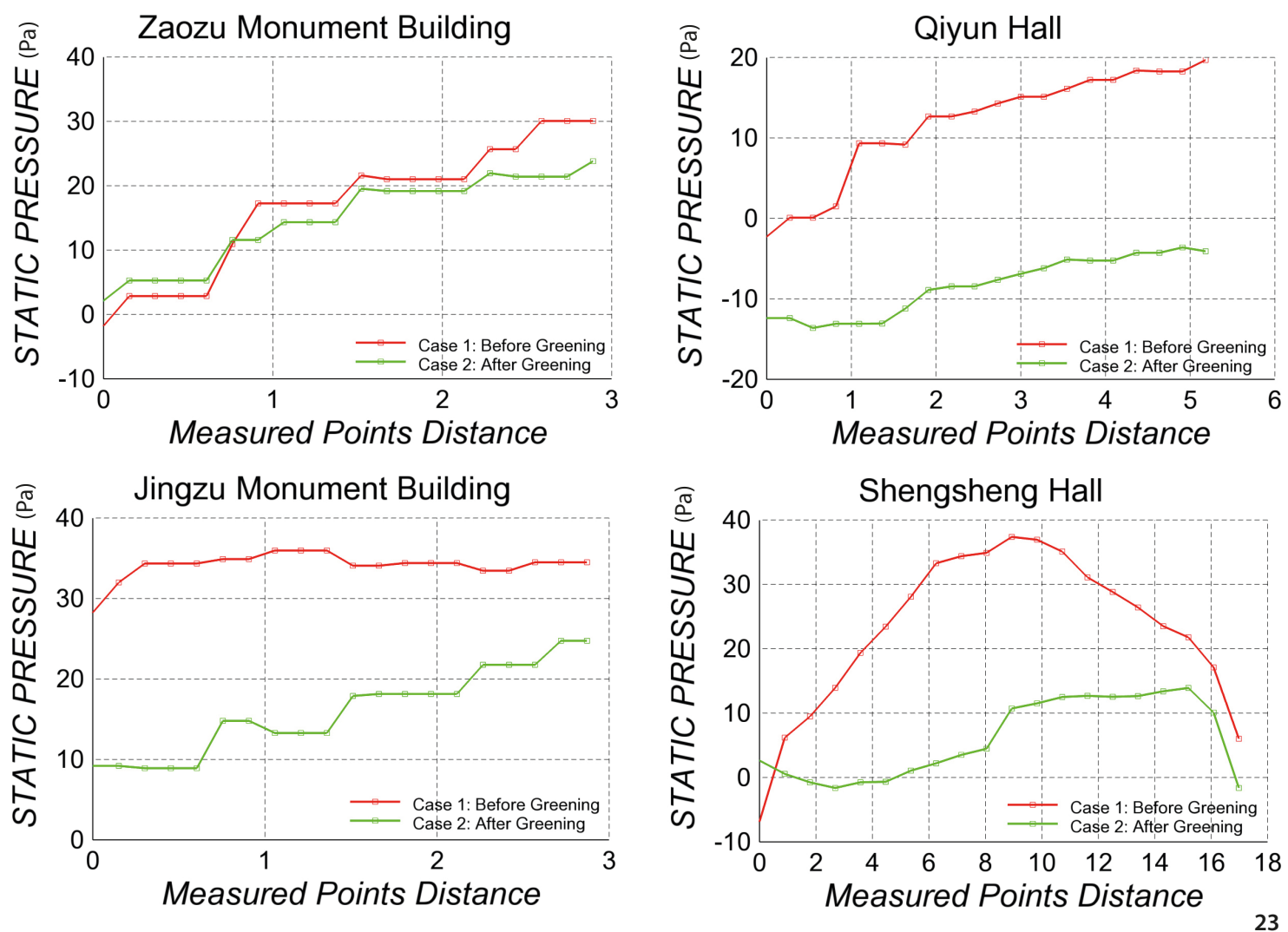

Figure 23 Wind pressure at places where swirling winds develop, after greening (Source: Xiaoyu Wang).
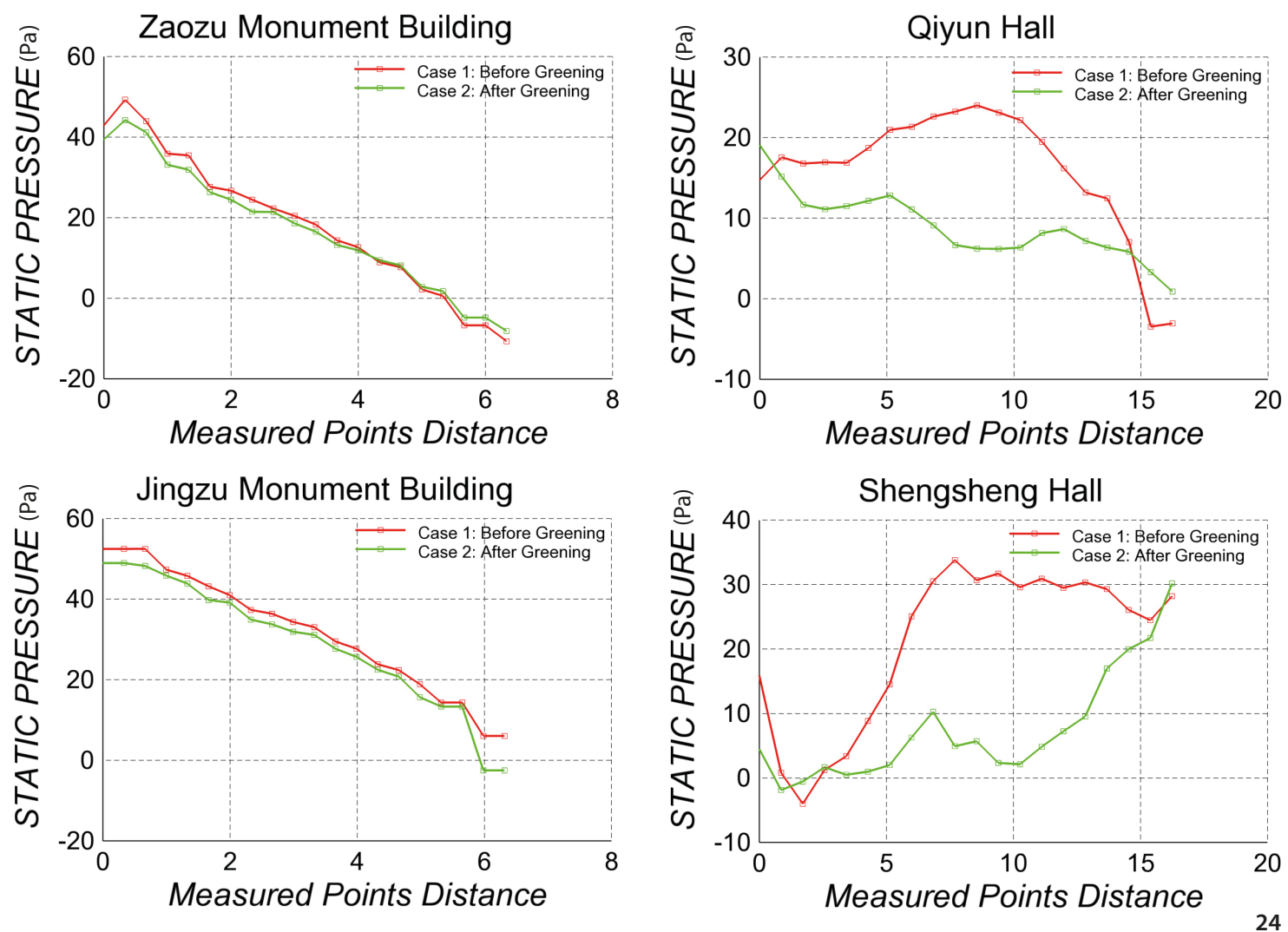

Figure 24 Wind pressure on the eaves of sloping roofs, after greening (Source: Xiaoyu Wang). 

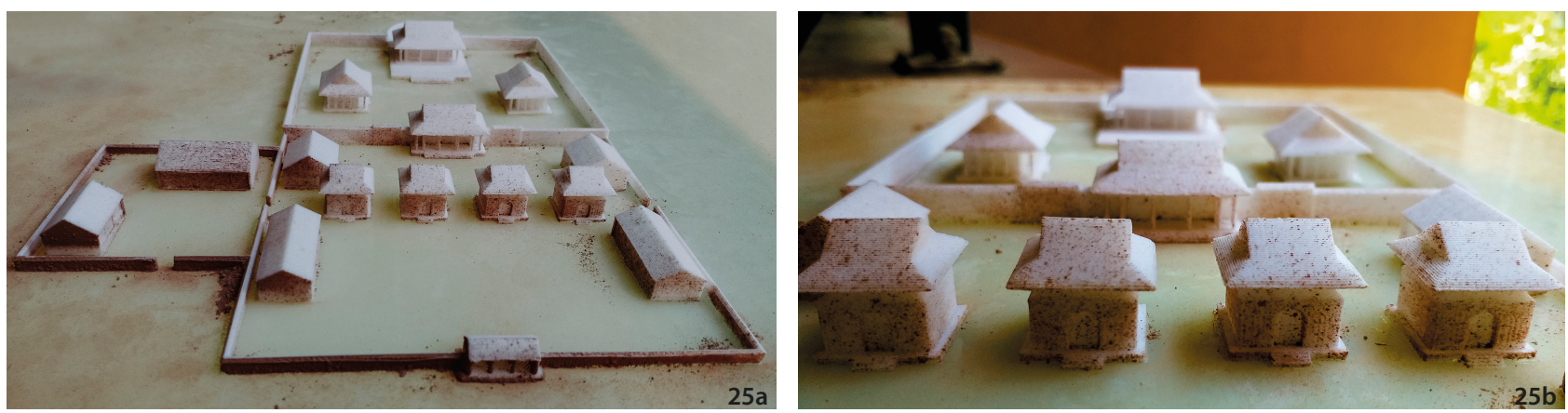

Figure 25 Wind erosion experiment on 1:500-scaled model (Source: Xiaoyu Wang).

to protect key structures of the heritage buildings seriously eroded by wind (Ortiz and Ortiz 2016). This alternative solution contrasts with normal treatments, wherein damaged stone bricks on roofs, walls, floors, foundations and steps are repaired by spraying anti-weathering solution of appropriate concentrations. Filling, repainting, and the infiltration and reinforcement of colour paintings have been suggested in fixing holes and cracks in roofs, walls, columns, doors, and windows (Dai and Zhang 2014). Finally, the rigidity of different materials, which may elicit different effects on heritage buildings eroded by wind, have not been detailed as yet. These will be completed in future work.

\section{Acknowledgments}

This study was supported by the National Natural Science Foundation of China (No. 51978417), Natural Science Foundation of Liaoning Province (2019-ZD-0207), Scientific research project of the Educational Department of Liaoning Province (LJGD2019012) and Education and the Teaching Reform Project of Shenyang University of Technology, China.

The authors are also grateful to the students of Class 1501, Class 1601, and Class 1701 in architecture, Shenyang University of Technology, for the surveying and mapping drawings of the Yongling Mausoleum in September 2018.

\section{References}

AIJ (Architectural Institue of Japan). 2006. Jianzhu yu chengshi kongjian lvhua guihua [Building and Urban Space Greening Planning]. Beijing: China Machine Press.

ANSYS, I. 2015. ANSYS FLUENT 16.0. Theory Guide. http://www.ansys.com

Bitog, J. P., I.-B. Lee, H.-S. Hwang, M.-H. Shin, S.-W. Hong, I.-H. Seo, K.-S. Kwon, E. Mostafa, and Z. Pang.
2012. "Numerical Simulation Study of a Tree Windbreak." Biosystems Engineering 111 (1): 40-48.

Blocken, B. 2015. "Computational Fluid Dynamics for Urban Physics: Importance, Scales, Possibilities, Limitations and Ten Tips and Tricks Towards Accurate and Reliable Simulations.” Building and Environment (91): 219-245.

Blocken, B., S. Roels, and J. Carmeliet. 2007. "A Combined CFD-HAM Approach for Wind-driven Rain on Building Facades." Journal of Wind Engineering and Industrial Aerodynamics 95 (7): 585-607.

Dai, Shibing, and Peng Zhang. 2014. Lishi jianzhu cailiao xiufu jishu daoze [Proposed Technical Guideline for Conservation of Historic Architectural Materials]. Shanghai: Tongji University Press.

Dong, F., D. Liu, and D. He. 1995. "Research Progress and Development Trends of Wind and Sand Movement." Advances in Mechanics 25 (3): 368-382.

Gromke, C., and B. Blocken. 2015. "Influence of Avenuetrees on Air Quality at the Urban Neighborhood Scale. Part I: Quality Assurance Studies and Turbulent Schmidt Number Analysis for RANS CFD Simulations." Environment Pollution 196: 214-223.

Hanna, Steven R., Gary A. Briggis, and Rayford P. Hosker Jr. 1982. Handbook on Atmospheric Diffusion. DOE/ TIC-11223. Technical Information Center, U.S. Department of Energy, Washington, DC.

Hong, B., and J. Luo. 2015. Landscaping Design Strategy to Improve Outdoor Microclimate in Residential Areas. Xi'an: Northwest Agriculture and Forestry University Press.

Kaltschmitt, Martin, Wolfgang Streicher, and Andreas Wiese, eds. 2007. Renewable Energy: Technology, Economics, and Environment. Springer.

Ji, Yaqin, Chunyan Shan, and Baoqing Wang. 2015. Turang fengshi yuanli he yanjiu fangfa ji kongzhi jishu [Principle, Research Method and Control Technology of Soil 
wind Erosion]. Beijing: Science Press.

Langenbach, R. 2007. "From 'Opus Craticium' to the 'Chicago Frame': Earthquake-Resistant Traditional Construction." International Journal of Architectural Heritage 1 (1): 29-59.

Martin Kaltschmitt, W. S., and Andreas Wiese. 2007. Renewable Energy: Technology, Economics, and Environment. Springer.

Orszag, S. A. a. Y., V. 1986. "Renormalization Group Analysis of Turbulence." In Proceedings of the International Congress of Mathematicians, Berkeley, 1395-1399.

Orszag, S. A., V. Yakhot, W. S. Flannery, F. Boysan, D. Choudhury, J. Maruzewski, and B. Patel. 1993. "Renormalization Group Modeling and Turbulence Simulations." In International Conference on Near-Wall Turbulent Flows, Tempe, Arizona.

Ortiz, R., and P. Ortiz. 2016. "Vulnerability Index: A New Approach for Preventive Conservation of Monuments." International Journal of Architectural Heritage 10 (8): 1078-1100.

Pineda, P., and A. Iranzo. 2017. "Analysis of Sand-Loaded Air Flow Erosion in Heritage Sites by Computational Fluid Dynamics: Method and Damage Prediction." Journal of Cultural Heritage 25: 75-86.

Tong, Z., R. W. Baldauf, V. Isakov, P. Deshmukh, and K. Max Zhang. 2016. "Roadside Vegetation Barrier Designs to Mitigate Near-road Air Pollution Impacts." Science of the Total Environment 541: 920-927.

Xiao, Yongqin, and Yaoqing Sun. 2016. Zhiwu peizhi yu zaojing [Plant Configuration and Landscaping]. Beijing: China Agricultural University Press.

Zhan, K., S. Liu, Z. Yang, E. Fang, L. Zhou, and N. Huang. 2016. "Effects of Sand-Fixing and Windbreak Forests on Wind Flow: A Synthesis of Results from Field Experiments and Numerical Simulations." Journal of Arid Land 9 (1): 1-12.

Zhang, H., and J. Cheng. 2014. Principles of Soil Erosion, 3rd Edition. Beijing: Science Press. 